\title{
The Effect of Long Public Holidays on Healthcare-associated Infection Rate
}

\author{
Uzun Tatillerin Hastane Enfeksiyonları Üzerine Etkisi
}

(i) Oğuz KARABAY1, id Gülsüm KAYA², id Ertuğgul GÜÇLÜ1, iD Aziz ÖĞÜTLÜ1

1Sakarya University Faculty of Medicine, Department of Infectious Diseases and Clinical Microbiology, Sakarya, Turkey

2Sakarya University Training and Research Hospital, Infection Control Committee, Sakarya, Turkey

\section{ABSTRACT}

Objective: Healthcare-associated infections (HAIs) are infections that cause serious mortality and morbidity. This study aimed to investigate the effect of long public holidays on HAIs rates in the intensive care units (ICUs).

Methods: The study was conducted in tertiary university education and research hospital, from January 2014 to October 2015. All ICUs are monitored daily by the infection control team by the active surveillance method. In this study, LPH and normal working periods (NWT) that develop HAIs, the bacterial factors that cause HAIs, between periods mortality rates, and overall mortality rates were compared. All data were analyzed with the Epi-Info program (Atlanta, USA) and p-values of $<0.05$ were considered statistically significant.

Results: During the study period, 3082 patients in the ICU were followed up. The HAI rate was 3.5\% in NWT and $16.5 \%$ in LPH $(\mathrm{p}=0.001)$. The examination of bacterial distribution that causes HAIs revealed significantly higher gram-negative bacterial infections in LPH than in NWT [13.7\% and 2.4\%, respectively $(\mathrm{p}=0.001)]$. The mortality rate examination revealed no significant difference in the overall mortality rates between study periods $(\mathrm{p}=0.769)$; infection-related mortality rates were significantly higher in LPH (7.3\%; $\mathrm{p}=0.002)$.

Conclusion: HAIs are affected by LPH. All employees should be motivated to prevent HAIs and should be trained for infection control measures before and after the holidays.

Keywords: Long public holidays, healthcare-associated infections, intensive care unit

\section{ÖZ}

Amaç: Sağlık bakımı ilişkili enfeksiyonlar (SBİE) ciddi mortalite ve morbiditeye neden olan enfeksiyonlardır. Bu çalışmada yoğun bakım ünitelerinde (YBÜ) uzun tatil dönemlerinin (UTD) SBİE oranları üzerine etkisi araştırıldı.

Yöntemler: Çalışma, Ocak 2014 ile Ekim 2015 arasında üçüncü basamak bir eğitim ve araştırma hastanesinde yapıldı. Tüm YBÜ, enfeksiyon kontrol ekibi tarafindan günlük olarak aktif gözetim yöntemi ile izlenmektedir. Bu çalışmada, UTD ve normal çalışma dönemlerinde (NÇD) gelişen SBİE, SBİE'ye neden olan bakteriyel etkenler, dönemler arası mortalite oranları ve genel mortalite oranları karşılaştırıldı. Tüm veriler Epi-Info programı (CDC, Atlanta, ABD) ile analiz edildi ve $\mathrm{p}<0,05$ değeri istatistiksel olarak anlamlı kabul edildi.

Bulgular: Çalışma döneminde YBÜ'de 3.082 hasta takip edildi. NÇD'de SBİE oranı \%3,5 ve UTD'de \%16,5 idi ( $\mathrm{p}=0,001)$. SBİE’ye neden olan bakteriyel dağılım incelendiğinde, Gramnegatif bakterileri enfeksiyonları UTD'de NÇD'ye göre anlamlı olarak yüksekti [sırasıyla; \%13,7; \%2,4 ( $\mathrm{p}=0,001)$ ]. Mortalite oranları incelendiğinde, çalışma periyotları arasında toplam mortalite oranları arasında anlamlı bir fark yokken $(\mathrm{p}=0,769)$; enfeksiyona bağlı mortalite oranları UTD'de anlamlı olarak daha yüksek saptandı $(\% 7,3 ; \mathrm{p}=0,002)$.

Sonuç: SBİE UTD'den etkilenmektedir. Tüm çalışanlar SBİE’nin önlenmesi için motive edilmeli, tatilden önce ve sonra enfeksiyon kontrol önlemleri konusunda eğitilmelidir.

Anahtar Sözcükler: Uzun tatil dönemi, sağlıkla ilişkili enfeksiyonlar, yoğun bakım ünitesi

Address for Correspondence: Oğuz KARABAY, Sakarya University Faculty of Medicine, Department of

Received: 02.06.2020 Infectious Diseases and Clinical Microbiology, Sakarya, Turkey

E-mail: drkarabay@yahoo.com ORCID ID: orcid.org/0000-0003-1514-1685

Cite this article as: Karabay O, Kaya G, Güçlü E, Öğütlü A. The Effect of Long Public Holidays on Healthcare-associated Infection Rate. Bezmialem Science 2022;10(1):68-72 


\section{Introduction}

Healthcare-associated infection (HAI) is an important health problem. Today, many complicated procedures and invasive procedures are frequently performed. These situations increase the risk of HAI. HAIs can cause functional impairment, decreased quality of life, and deaths. Additionally, prolonged hospital stay increased antibiotic consumption, isolation costs, workload, and economic losses (1-3).

Some days are official holidays in Turkey, such as April 23 (National Sovereignty And Children's Day), May 19 Commemoration of Atatürk, Youth and Sports Day), August 30 (Independence Day), and October 29 (Republic Day), as well as some religious holidays, such as Ramadan and Qurban (Literally, "sacrifice"). Sometimes, on these official and religious festivals, long public holidays (LPH) are granted by the government, and allowances are sometimes extended up to 9 days. The LPH, which includes long working hours, disruptions, and problems that occur in transportation, communication, security, and health services. Hospitals are one of the most affected institutions from LPH because primary healthcare centers are closed $(4,5)$. In our country, the most social mobility is seen during these holidays. Patients are generally admitted to the emergency services in LPHs. As both primary healthcare centers are closed and patients can only apply to the emergency department of hospitals, working as a hospital healthcare personnel during these periods becomes difficult. Moreover, the workload of the health care practitioner is also higher in LPHs than normal working hours (5-7). Contrary to the workload, more inexperienced personnel are employed during the LPH. Furthermore, these inexperienced staffs are working on duty for a long time and are exhausted (5-8). Therefore, infection control was thought to be easily compromised from the measures of these exhausted personnel (9). Moreover, many employees with controlled duties are permitted in those periods. Thus, staffs who are not concerned about monitoring can ignore infection control measures $(6,7,10)$.

Our research revealed that a study published in English, which investigated the risk of hospital infection during LPHs, is not accessible. Therefore, this study aimed to investigate the effect of LPHs on the risk of infection.

\section{Methods}

\section{Working Design and Data Collection}

During the study period, reanimation, neurology, cardiovascular surgery, and surgical intensive care unit (ICU) were monitored daily by the active surveillance method of the infection control team.

\section{Study Periods}

The study was carried out between January 01, 2014, and October 10, 2015, in tertiary university education and research hospital with a total capacity of 900 beds.

\section{LPH}

LPH was defined as public holidays that are $\geq 4$ days including weekends. This study included patients who are hospitalized in the ICUs for $>1$ day. Upon unit admission, patients who are infected and colonized were excluded from the study. The number of patients, the day of hospitalization, and the developing HAI information were obtained from the surveillance files.

\section{Normal Working Time (NWT)}

NWT was defined as normal working periods that do not include any public holidays without weekends. During this period, patients who are hospitalized in the ICU for $>1$ day, as in LPH, were included in the study, whereas patients who were infected and colonized upon admission were excluded. During NWT, the number of inpatients, patient days, and developing HAI rates were obtained from the surveillance records.

\section{Infection-related Mortality Rate}

Patients who died within the first 28 days after the infection diagnosis was accepted as infection-related death. The infectionrelated mortality rate was calculated with this formula: patients who died within 28 days after the infection diagnosis $\div$ patients followed up in the relevant period (LPH/NWT) x100.

\section{Overall Mortality Rate}

Patients who died from non-infectious causes 28 days after the infection diagnosis were accepted as the overall mortalityrelated death. The overall mortality rate was calculated with this formula: patients who died from non-infectious causes 28 days after infection diagnosis $\div$ patients followed up in the relevant period (LPH/NWT) x100.

\section{Inclusion Criteria}

All patients in the ICU of our hospital were included in the study. The infection and colonization discrimination of patients was performed according to the diagnostic criteria of the hospital infection of the Center for Diseases Control (z) (11).

\section{Exclusion Criteria}

Patients with colonization and patients under 18 years old were excluded from the study.

\section{Ethical Consent}

Ethical approval of this study was obtained from Sakarya University Medical Faculty Ethics Committee with the application dated 04/17/2017: document number: 85/2017.

\section{Statistical Analysis}

Data were evaluated in Epi-info (CDC, Atlanta, USA) 6.0 computer program. The Student t-test was used to evaluate quantitative variables, and chi-square and yates corrected chisquare tests were used to evaluate qualitative data. p-values of $<0.05$ were considered significant.

\section{Results}

During the study period, 3082 patients were followed in the ICUs. The number of patients in LPH was 109 and patient days was 993. The number of patients in NWT was 2,973 and patient days was 23,044. The rate of HAI was $16.5 \%(n=18)$ in LPH, whereas $3.5 \%(n=106)$ in NWT and there was a significant 
difference between LPH and NWT [ $\mathrm{p}=0.001$, odds ratio (OR): $5.35,3.00<\mathrm{OR}<9.45)$. A total of $18(16.5 \%)$ HAI develops in $\mathrm{LPH}$, whereas $16(3.5 \%)$ in NWT $(\mathrm{p}=0.001)$. Central venous catheter-related bloodstream infection was the HAIs in LPH. Similarly, the most common HAI in NWT was central venous catheter-related bloodstream infection (Table 1). Table 1 presents the distribution of HAI according to periods. Gram-negative bacteria that are detected as a pathogen of nosocomial infection were more frequently observed in LPH than in NWT [13.7\% vs. $2.4 \%$, respectively $(\mathrm{p}=0.001)$ ] (Table 2$)$. In both LPH and NWT, the most common cause of HAI was Gram-negative bacteria, such as Klebsiella pneumoniae and Enterococcus spp. The overall mortality rate was $28.4 \%(31 / 109)$ and $29.7 \%(883 / 2,973)$ in LPH and NWT, respectively $(\mathrm{p}=0.777)$. Infection-related mortality rate was significantly higher in LPH [7.3\% (8/109)] than in NWT $[2.5 \%(74 / 2973)](\mathrm{p}=0.001)$. Mortality rates were given in Figure 1.

\section{Discussion}

Hand hygiene and infection control measure compliance has shown an effect in reducing health-related infection rates $(12,13)$. Hand hygiene compliance with a hand hygiene education program was reported to increase from 46\% to $69 \%$ $(\mathrm{p}<0.0001)$ and the nosocomial sepsis rate decreased from $96 \%$ to $47 \%(\mathrm{p}<0.0001)(14)$. Hand hygiene compliance with the hand hygiene program was significantly increased from $25.7 \%$ to $57.5 \%(\mathrm{p}<0.001)$, and the incidence of HAIs was $31.7 \%$ from $20.3 \%(\mathrm{p}<0.001)(15)$. However, if the healthcare personnel are subject to a heavy workload, many infection control measures are compromised, especially hand hygiene (16). This study revealed that more infections may occur if healthcare personnel is exposed to a heavy workload during LWP. Mortality in LPHs is higher than in NWT. This is also evident in infection-related mortality. The increased mortality due to infection is thought to be related to the increased work intensity per employee. A study reported that mortality increased by 3.5 times higher with the nurse bed ratio at $<1 / 2.5$ in the same study period. When the doctor/bed ratio was above $1 / 14$, the mortality increased 2 times (20). A retrospective observational study conducted in the

\begin{tabular}{|c|c|c|c|}
\hline $\begin{array}{l}\text { Distribution of } \\
\text { healthcare-associated } \\
\text { infections }\end{array}$ & $\begin{array}{l}\text { Long } \\
\text { public } \\
\text { holidays } \\
(\mathrm{n}=109) \\
\mathrm{n}(\%)\end{array}$ & $\begin{array}{l}\text { Normal } \\
\text { working } \\
\text { time } \\
(\mathrm{n}=2,973) \\
\mathrm{n}(\%)\end{array}$ & $\mathrm{p}$-value \\
\hline $\begin{array}{l}\text { Central venous } \\
\text { catheter-related blood } \\
\text { circulation infection }\end{array}$ & $11(10.0)$ & $75(2.5)$ & 0.001 \\
\hline $\begin{array}{l}\text { Laboratory-based blood } \\
\text { circulation infection }\end{array}$ & $6(5.5)$ & $15(0.5)$ & 0.001 \\
\hline Soft tissue infection & $1(0.9)$ & 0 & 0.001 \\
\hline Other infections & 0 & $16(0.53)$ & 0.442 \\
\hline Total & $18(16.5)$ & $106(3.5)$ & 0.001 \\
\hline
\end{tabular}

United Kingdom with quite a lot of patients $(n=38,168)$ revealed that survival improved as the number of both doctors and nurses increased (21).

One study revealed that infection-related mortality is higher in LPHs than in NWT. Hospital mortality rates were seen higher in LPH than NWT (17). This situation may be related to the amount of work per staff member in LPH. Many staff does not come to work in LPH, thus the services work with full capacity. Healthcare personnel who are obliged to train a specific job at this time can easily abandon the necessity of compliance with hospital cleaning or isolation measures. Additionally, our study revealed that hygiene practices should be monitored in LPH. Acute hospitals provide roundthe-clock services, 7 days a week; however, the number of personnel (seniority and number) is seen lower on weekends than on weekdays (22). Nurse inadequacy and increased nursing workload have been associated with an increased risk of adverse patient outcomes (e.g., falls, decubitus, medication administration errors, healthcare-related infections, unplanned extubations, and mortality), as well as nurse burnout and job dissatisfaction (23).

During LPH, intensive care workers are exposed to a heavy workload per capita. The number of experienced staff in LPHs

Table 2. Bacterial agent distribution of healthcareassociated infections during long public holidays and normal working time

\begin{tabular}{|c|c|c|c|}
\hline Microorganism & $\begin{array}{l}\text { Long public } \\
\text { holidays } \\
(n=109) \\
n(\%)\end{array}$ & $\begin{array}{l}\text { Normal } \\
\text { working } \\
\text { time } \\
(n=2,973) \\
n(\%)\end{array}$ & $\mathrm{p}$-value \\
\hline Gram-positive & $1(0.9)$ & $11(0.3)$ & 0.367 \\
\hline Enterococcus spp. & $1(0.9)$ & $7(0.2)$ & 0.169 \\
\hline Staphylococcus aureus & 0 & $2(0.06)$ & 0.786 \\
\hline $\begin{array}{l}\text { Coagulase negative } \\
\text { Staphylococcus }\end{array}$ & 0 & $2(0.06)$ & 0.786 \\
\hline Gram-negative & $15(13.7)$ & $72(2.4)$ & 0.001 \\
\hline $\begin{array}{l}\text { Acinetobacter } \\
\text { baumannii }\end{array}$ & $1(0.9)$ & $15(0.5)$ & 0.555 \\
\hline $\begin{array}{l}\text { Pseudomonas } \\
\text { aeruginosa }\end{array}$ & $2(1.8)$ & $13(0.4)$ & 0.039 \\
\hline Klebsiella pneumoniae & $6(5.5)$ & $37(1.2)$ & 0.0001 \\
\hline Escherichia coli & $2(1.8)$ & $3(0.1)$ & 0.001 \\
\hline Serratia marcescens & $1(0.9)$ & $2(0.06)$ & 0.005 \\
\hline Enterobacter cloacae & $2(1.8)$ & $1(0.03)$ & 0.001 \\
\hline Citrobacter & $1(0.9)$ & 0 & 0.001 \\
\hline Proteus mirabilis & 0 & $1(0.03)$ & 0.964 \\
\hline Fungi & $2(1.8)$ & $23(0.7)$ & 0.503 \\
\hline Candida spp. & $2(1.8)$ & $23(0.7)$ & 0.503 \\
\hline Total & $18(16.5)$ & $106(3.5)$ & 0.001 \\
\hline
\end{tabular}




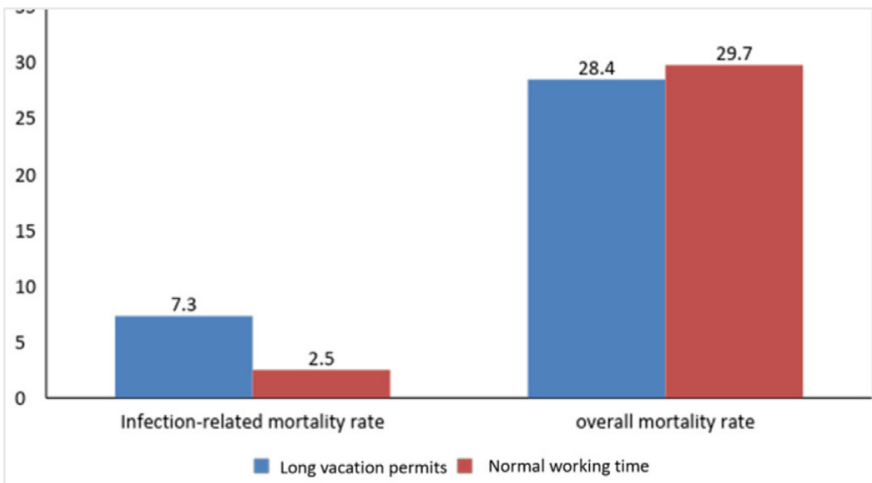

Figure 1. General mortality and infection-related mortality rates during long public holidays and normal working time

is less than the NWT. Additionally, many invasive procedures are performed with less qualified personnel (8). Therefore, the development of infection due to invasive procedures increases, as well as the infection frequency. Moreover, the number of staff in charge of the supervision is decreasing in LPHs. Employees may exhibit sloppy behavior when they feel that they are not being monitored or controlled. Thus, many measures, such as hand washing, wearing gloves, or adapting to isolation measures, may be inconvenient. A study on feedback to the healthcare workers showed a significantly decreased central venous catheterassociated bloodstream infections (17).

Hospital surface cleaning is thought to be much worse in these periods since the number of staff involved in the resettlement is less than the normal period and the unit work volume per staff is much higher. The deterioration of all these functions also brings about deterioration. Significantly, more gram-negative and yeast infections are observed. LPHs understandably had the highest level of contamination due to grove turnover and the greater number of patients and staff workload seemed less sensitive in prioritizing the hygiene in these periods (19). The heavy workload in the work shift also increases the probability of hospital infections (24).

\section{Conclusion}

Therefore, LPH is disadvantageous for HAI. Prevention of HAI is a process that begins with a patient's hospital admission. Healthcare personnel should be aware that HAI is preventable. An education plan for infection control measures should be established, training should be made continuous and repeated before and after an LPHs. LPH significantly influences hygiene and infection control, facilitates the spread of pathogenic bacteria, and increases infection-related deaths. Therefore, infection control precautions should be more frequently supervised in LPHs.

\section{Ethics}

Ethics Committee Approval: Ethical approval of this study was obtained from Sakarya University Medical Faculty Ethics Committee with the application dated 04/17/2017: document number: 85/2017.
Peer-review: Internally and externally peer reviewed.

\section{Authorship Contributions}

Concept: O.K., G.K., E.G., A.Ö., Design: O.K., G.K., E.G., A.Ö., Data Collection or Processing: O.K., G.K., E.G., A.Ö., Analysis or Interpretation: O.K., G.K., E.G., A.Ö., Literature Search: O.K., G.K., E.G., A.Ö., Writing: O.K., G.K., E.G., A.Ö.,

Conflict of Interest: No conflict of interest was declared by the authors.

Financial Disclosure: The authors declared that this study received no financial support.

\section{References}

1. Saint S. A new strategy to combat hospital infections. Preventing hospital infections. 2014;1-8.

2. HSU V. Prevention of health care-associated infections. Am Fam Physician 2014;6:377-82.

3. Magill SS, Leary O, Janelle SJ, Thompson DL, Dumyati G, Nadle J, et al. Changes prevelance oh healthcare-associated infections in U.S. Hospitals. N Engl J Med 2018;18:1732-44.

4. Bol O, Altuntaş M, Kaynak MF, Koyuncu S, Biçer M, Öner G, et al. The Effect of Long Term Holidays on Emergency Services. JAMER 2019;4:13-22.

5. Dagar S, Sahin S, Yilmaz Y, Durak U. Emergency Department During Long Public Holiday. Turk J Emerg Med 2014;14:165-71.

6. Kosucu S, Goktas SB, Yıldız T. Hand hygiene compliance rate of health professionals. MÜSBED 2015;5:105-8.

7. Snyder R. Hardwiring hand hygiene among staff members. Nurs Manage 2008;39:14.

8. Mohammed MA, Sidhu KS, Rudge G, Stevens AJ. Weekend admission to hospital has a higher risk of death in the elective setting than in the emergency setting: a retrospective database study of national health service hospitals in England. BMC Health Serv Res 2012;12:87.

9. Pohlman C. Issues in hiring and supervising professional staff and support personnel. In: Walfish S, Brnet JE, Zimmerman J, editors. Handbook of Private Practice: Keys to Success for Mental Health Practitioners. Oxford Universty Press; 2017.P170.

10. Bearman G, Munoz-Price S, Morgan DJ, Murthy RK. Infection prevention: New perspectives and controversies. Springer. 2017;315 p.

11. Guidelines Library | Infection Control | CDC (n.d.). Available at https://www.cdc.gov/infectioncontrol/guidelines/index.html. Accessed January 12, 2019.

12. Shabot MM, Chassin MR, France A-C, Inurria J, Kendrick J, Schmaltz SP. Using the targeted solutions Tool $^{\circledR}$ to improve hand hygiene compliance is associated with decreased healthcare-associated infections. Jt Comm J Qual Patient Saf. 2016;42:6-17.

13. Sadeghi-Moghaddam P, Arjmandnia M, Shokrollahi M, Aghaali M. Does training improve compliance with hand hygiene and decrease infections in the neonatal intensive care unit? A prospective study. J Neonatal Perinatal Med 2015;8:221-5. 
14. Chhapola V, Brar R. Impact of an educational intervention on hand hygiene compliance and infection rate in a developing country neonatal intensive care unit. Int J Nurs Pract 2015;21:486-92.

15. Thi Anh Thu L, Thi Hong Thoa V, Thi Van Trang D, Phuc Tien N, Thuy Van D, Thi Kim Anh L, et al. Cost-effectiveness of a hand hygiene program on healthcare-associated infections in intensive care patients at a tertiary care hospital in Vietnam. Am J Infect Control 2015;43:e939.

16. Zhang S, Kong X, Lamb KV, Wu Y. High nursing workload is a main associated factor of poor hand hygiene adherence in beijing, China: An observational study. Int J Nurs Pract 2019;25:e12720.

17. Smith S, Allan A, Greenlaw N, Finlay S, Isles C. Emerhency medical admission, deaths at weekends and the public holiday effect. Cohort study. Emerg Med J 2014;31:30-4.

18. Cherifi S, Byl B, Deplano A, Nonhoff C, Denis O, Hallin M. Comparative epidemiology of Staphylococcus epidermidis isolates from patients with catheter-related bacteremia and from healthy volunteers. J Clin Microbiol 2013;51:1541-7.

19. Messina G, Ceriale E, Lenzi D, Burgassi S, Azzolini E, Manzi P.
Environmental contaminants in hospital settings and progress in disinfecting techniques. Biomed Res Int 2013;2013:429780.

20. Neuraz A, Guerin C, Payet C, Polazzi S, Aubrun F, Dailler F, et al. Patient mortality is associated with staff resources and workload in the ICU: a multicenter observational study. Crit Care Med 2015;43:1587-94

21. West E, Barron DN, Harrison D, Rafferty AM, Rowan K, Sanderson C. Nurse staffing, medical staffing and mortality in Intensive Care: An observational study. Int J Nurs Stud 2014;51:781-94.

22. The Audit Commission: Medical Staffing (report), Acute hospital portfolio London: 8 Audit Commission; 2002.

23. Jansson MM, Syrjala HP, Ala-Kokko TI. Association of nurse staffing and nursing workload with ventilator-associated pneumonia and mortality: a prospective, single-center cohort study. J Hosp Infect 2019;101:257-63.

24. Brown KL, Pagel C, Pienaar A, Utley M. The Relationship Between Workload and Medical Staffing Levels in a Paediatric Cardiac Intensive Care Unit. Intensive Care Med 2011;37:326-33. 